\title{
Facies Development of Carbonate Rock and System Tract Influence Based on Fullbore Formation Microimager (FMI) and Well Log Analysis on Carbonate Reservoir Tuban Formation, North East Java Basin
}

\author{
Fahrudin ${ }^{1, *}$, Eka Sainyakit ${ }^{1}$, Ahmad Syauqi Hidayatillah ${ }^{1}$, Purnaning Tuwuh Triwigati $^{1}$, Muhajir $^{2}$ \\ ${ }^{1}$ Geological Engineering Department, Diponegoro University, Semarang - Indonesia \\ ${ }^{2}$ Joint Operating Body Pertamina-Petrochina East Java, Jakarta - Indonesia
}

\begin{abstract}
The North East Java Basin is known to be one of the basins that consist of Miocene carbonate rocks, like the reef carbonate of Tuban Formation. It has the potential hydrocarbons that can be explored. Therefore, the FMI log analysis is very important to identify carbonate rocks of Tuban Formation to know facies and characteristics of that carbonate rocks. The method used descriptive and analysis process of FMI and Gamma Ray log to determine facies of the carbonate rock and the system tract. Based on the result of FMI log analysis, there are variations lithofasies include mudstone, wackestone, packstone, grainstone, floatstone, rudstone and claystone. A collection of rock associations can interpret the reef facies. It involves back reef facies, reef core facies, and fore reef facies. The changes of lithofasies and reef facies are caused by sea level fluctuations and subsidence resulting in the system tract. The system tracts generated in the research area include transgressive and highstand system tract.
\end{abstract}

Keywords: Tuban Formation; FMI log; Facies; System Tract

\section{Introduction}

The North East Java Basin is one of the gigantic fields that composed by Oligo-Miocene carbonate rocks and reef growth. The main reservoir in this basin is targeted at the Kujung and Tuban Formation that dominantly composed by carbonate rocks $[1,2,3,4]$. It is necessary to do FMI analysis in this basin to find out the facies characteristics of carbonate rocks in assisting the interpretation of gamma ray $\log$ analysis results that are not sensitive enough for carbonate facies analysis. FMI $\log$ is part of the imaging tool which is a tool that produces the image $\log$, with its appearance of the image resembles with the appearance of a core picture $[5,6,7,8]$. The aim of this research is to know the litholology or facies characteristic of carbonate rock and also to analyze the spread of carbonate rock facies to determine the prospect zone of Tuban Formation from 6 wells, namely Jebori (JBR) 28 well, JBR 34, JBR 35. JBR 14, JBR 3 and JBR 6.

\section{Methodology}

Well observation was conducted by using a descriptive method including literature study and case study on research area by conducting the FMI and gamma ray log analysis $[9,10]$. In determining the facies and system tract, there are several stages of research that were conducted: data collection including the data of FMI log, gamma ray log, core, mudlog, well basemap, and survey data. The next stage is data processing by using a software named Schlumberger Techlog. This data processing stage includes the image processing that processes the FMI data with (.dlis) extension into raw image data in the form of dynamic and static image, then the image data will be converted from TVD to TVDSS based on survey data. The next stage is determine the type of lithofacies and gamma ray log pattern analysis. The last step is doing the facies interpretation of carbonate rock and type of system tract in research area.

\section{Results and Discussion}

\subsection{Correlation of carbonate rocks facies}

From facies analysis, it is necessary to correlate between one with other facies so it can be interpreted the facies

\footnotetext{
* Corresponding author: fahru_gabru@yahoo.com
} 
distribution at Jebori Field. There are 4 lines of facies correlations based on the well position on the basemap.

- In line 1, it was found that facies that developed in JBR 28, JBR 35, JBR 34, and JBR 14 were fore reef, reef core, and back reef facies.

- In line 2 indicates the absence of the back reef facies as in JBR 6. It is interpreted that the location of the JBR 3 is still very close to the reef growth zone so that the finer-sized material is deposited further than JBR 3.

- In line 3, correlation was conducted by connecting JBR 28 and JBR 3 with SW-NE direction and it was found that getting north and northeast in the research area was dominated by the development of reef organisms.

- In line 4 , by connecting the similarity of carbonate rock facies with S-N direction on JBR 6 and JBR 14, it can be seen that back-reef facies developed towards the shallower depths. This explains that in the southern part is very far from the reef's growth and becoming a quiet depositional environment.
3D correlation that links the entire well at Jebori Field (Figure 3.1) indicates that in the north to the northeast area shows the deposition phase of carbonate rocks with the fine-sized lithology. This facies change from south to southwest in the research area showed very different facies. In the south to the southwest of the study area it can be seen that at the bottom of this well there are reef core facies and fore reef facies. It is interpreted that the development of organism builds up is very dominant, so the lithology here is the result of organism builds up that has been transported and deposited. However, the north side is dominated by reef core and fore reef facies which is very thick. The distribution of reef core facies is very thick from JBR 3 and it is increasingly depleted to the southwest to the south of the research area. The next phase is the deposition of fine-grained materials that produce the facies development changes of back reef facies. This is interpreted based on the top of carbonate structure map of the study area that explains that the southern region is located very far from the build up of reef organisms.

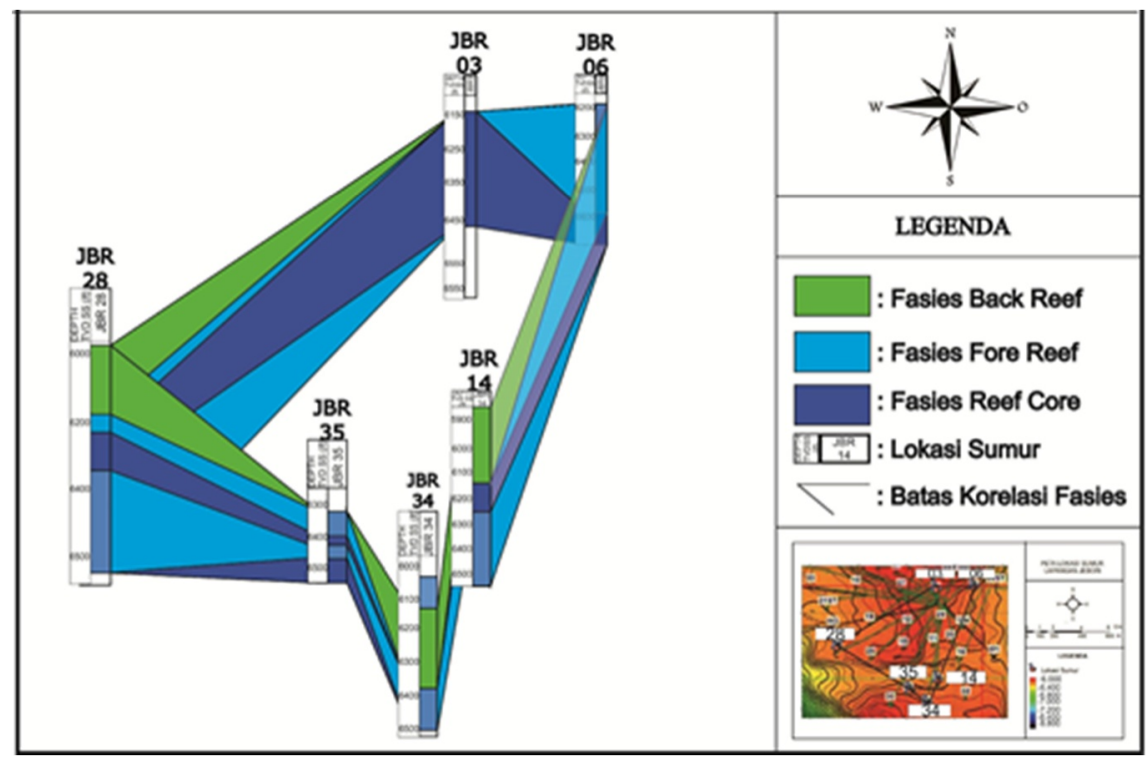

Fig. 3.1 A fence diagram correlation of carbonate rock facies at Jebori Field

\subsection{Stacking Pattern Analysis}

This stacking pattern analysis is based on gamma ray curve pattern. The stacking patterns of Jebori Field based on the results of gamma ray $\log$ analysis are: retrogradation and agradation. Retrogradation is formed when the sedimentation rate is smaller than the accomodation space growth [11]. This pattern is recognized by the increasingly gamma ray curve to the right that represents the gradual change in grain size. Based on the results of analysis on gamma ray log pattern, it can be seen that the presence of retrograde parasequence is characterized by the presence of gamma ray with 'bell' patterns. So based on analysis of the shape / pattern of the gamma ray, this parasequence can be found in JBR 28, JBR 34, JBR 35 and JBR 14 (Figure 3.2a). The pattern of agradation is formed when there is no visible displacement of contacts between electrofacies from one parasequence to the other. To determinate this kind of stacking pattern, it can be seen based on gamma ray curve that characterizes insignificant changes, so it can be interpreted that the deposition is constant and stable. Based on the results of gamma ray pattern analysis on Jebori Field, the agradation stacking pattern is characterized by the presence of 'serrated' and 'blocky' gamma ray pattern. This agradation is found in JBR 3 and JBR 6 (Figure 3.2b) 

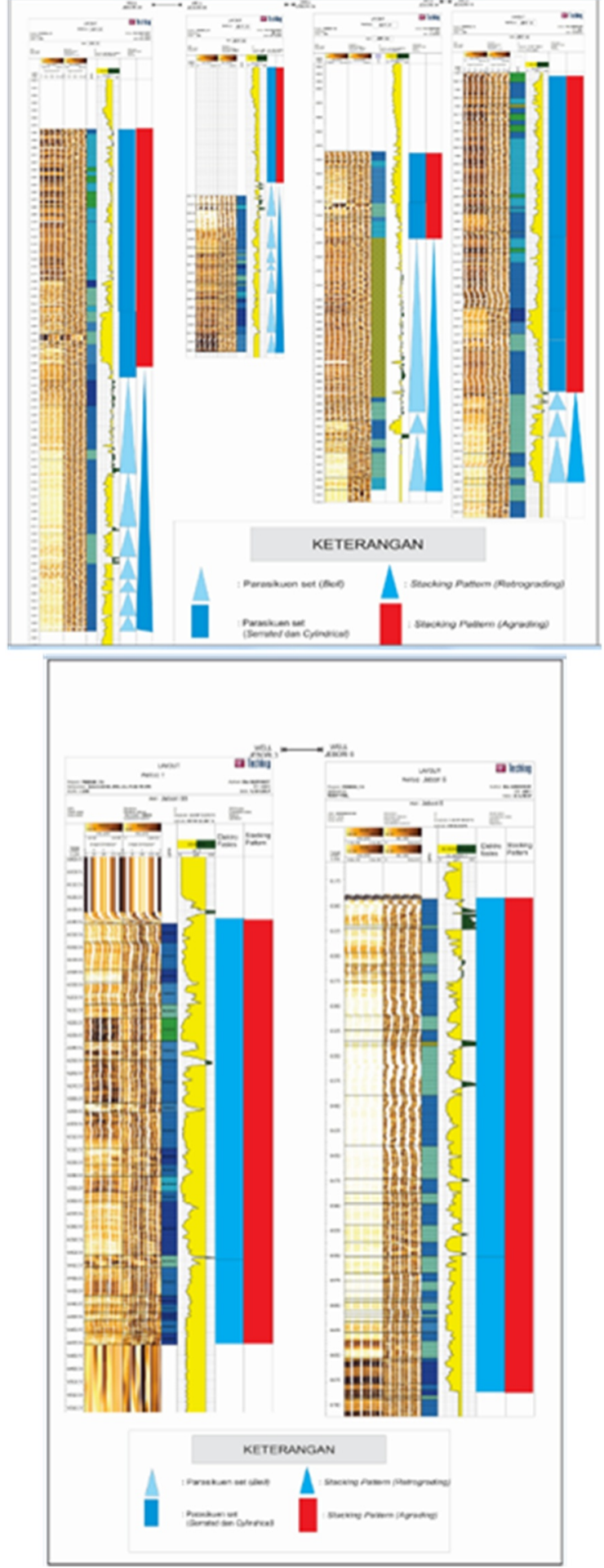

Fig. 3.2 (upper) The presence of stacking pattern in correlation line A (a) and (bottom) line B (b) on Jebori Field

\subsection{System Tract Correlation}

Correlation of this system tract using the Maximum Flooding Surface (MFS) marker. MFS boundaries are marked by the changes in gamma ray values that initially have low values and it will increase to high gamma ray values. The results of the analysis on line A (Figure 3.3a) shows that at JBR 28, JBR 34, JBR 35 and JBR 14 have Transgressive Sytem Tract phase (TST). At the top of the TST as the final phase of transgression is marked by the presence of MFS resulting the system tract change to the Highstand System Tract (HST) phase. The pattern change that can be seen after the TST phase is HST phase. This HST happens in 4 wells. This is indicated by the presence of 'serrated' gamma ray log pattern on JBR 28, JBR 35, JBR 34 and JBR 14. The result of analysis on line B (Figure 3.3b) shows that on JBR 3 and JBR 6 have HST phase. Both of these wells do not experience TST phase as in line $\mathrm{A}$. In line $\mathrm{B}$, the marker as the main thing in doing correlation also can't be found, so that the correlation on line B is equalized by the depth of True Vertcial Depth SubSea (TVDSS).

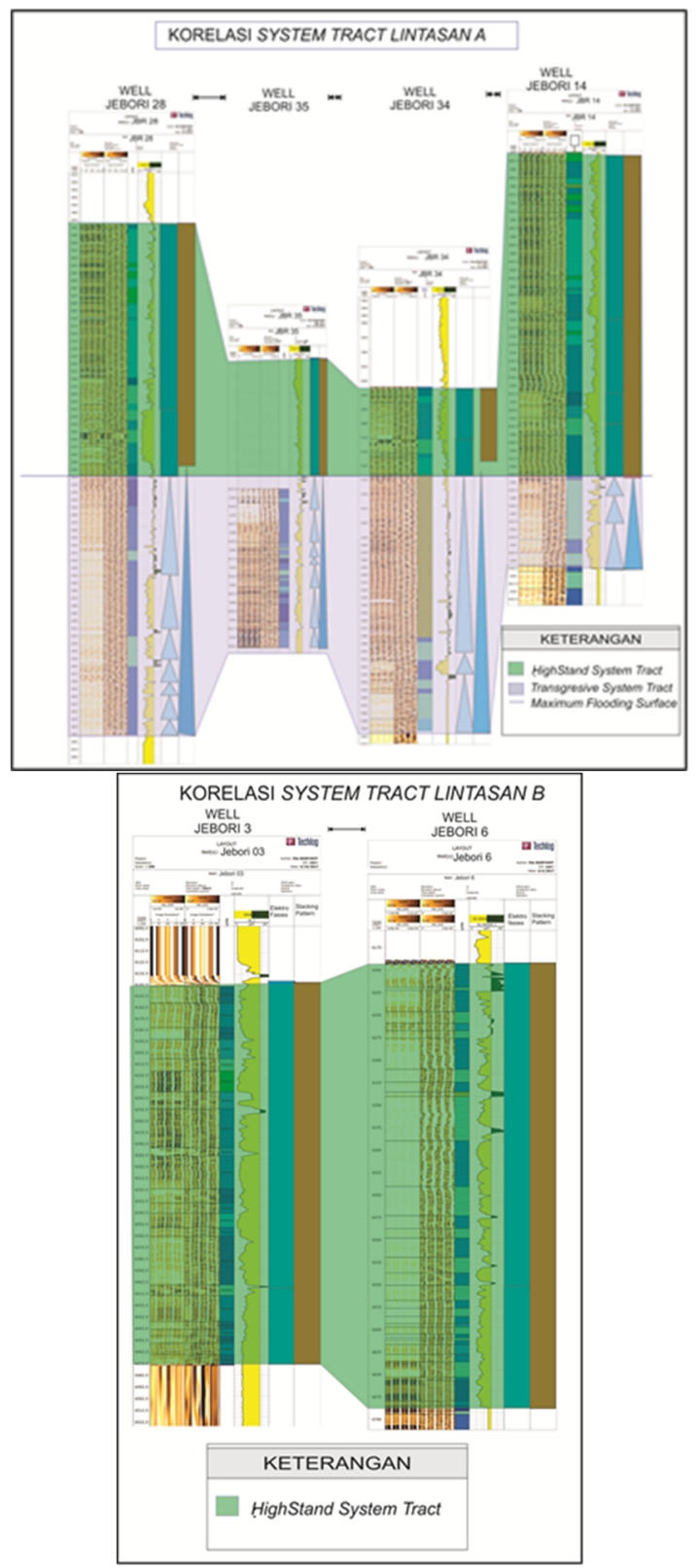

Fig. 3.3 (upper) The system tract correlation on line A (a) and (bottom) line B (b) on Jebori Field

\subsection{Depositional Model of Carbonate Facies}

This depositional model (Figure 3.4) from Jebori Field is associated with the Top Tuban Carbonate Map. The depositional process of carbonate rock is controlled by 
reef development that located in the northern and southern parts of research area. It can be interpreted that this field is controlled by several geological structures which make up the uplifted part and the lower part. The correlation of the reefs development in the northern and southern part is interpreted from the tectonic controls that happen the depositional process. Based on Lemigas (2003) in [12], in the middle Miocene, the tectonic phase of this time was compressional wrenching. The compressional wrenching phase that develops in the middle Miocene affects the vertical development of the shear faults to form a flower structure and causing the rapture in the north and south as well as the central basin. This tectonic effect is very influential in the deposition of Tuban Formation during the late Miocene. These highs and lows became the media in the deposition of carbonate facies in Jebori Field. The facies and system tract correlations in this research area indicated the initial sedimentation of Tuban Formation was dominated by the development of rudstone, grainstone, packstone, and floatstone lithofasies. This is highly correlated with regional stratigraphic condition that indicates the deposition of the transgression phase [13]. In this research area, if the depth is getting shallow, it will be found the back reef facies. The result of gamma ray log pattern analysis shows that there is a change of pattern from TST to HST in facies change to back reef. In this research area also can be found mudstone, wackstone and claystone lithofasies that are very dominant at the shallow depth that characterizes the back reef facies. The linkages of facies and system tracts of the research area are also correlated with regional conditions ie at the final deposition of the Tuban Formation itself is characterized by shale deposition.

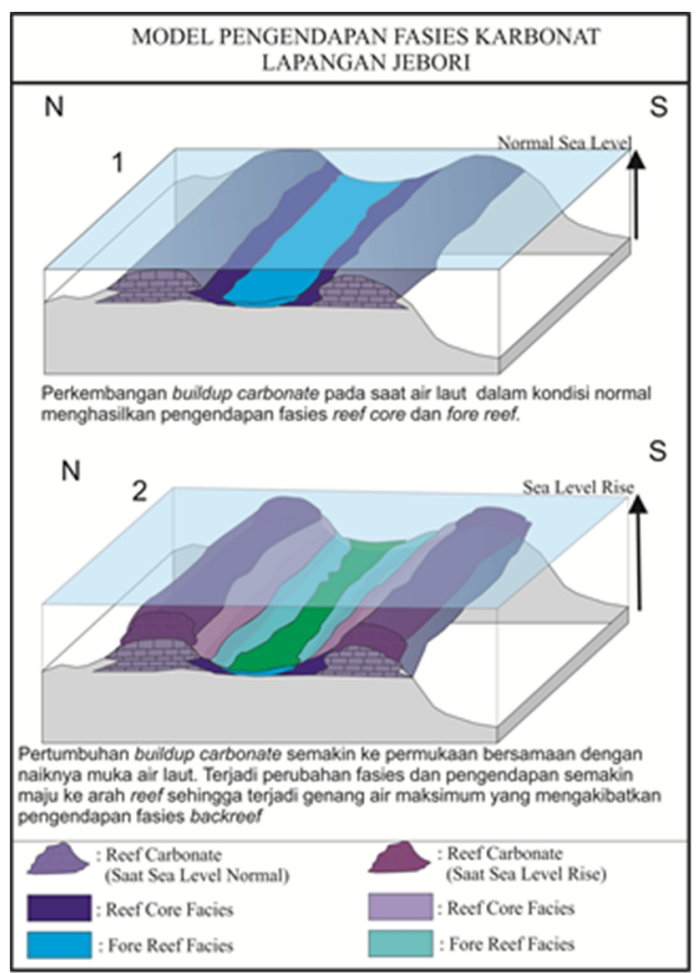

Fig. 3.4 Depositional model of carbonate facies and the effect of system tract on Jebori Field

\section{Conclusions}

Based on the results of facies analysis, JBR 28 has fore reef, reef core, fore reef and backreef facies. JBR 35 has core reef, fore reef, core reef and backreef facies. JBR 34 has a fore reef and backreef facies. JBR 14 has fore reef, reef core and backreef facies. JBR 3 has a reef core facies. JBR 6 has reef core and fore reef facies. Based on the analysis of gamma ray log pattern, the stacking patterns in the research area are agradation and retrogradation pattern, and in the first line is interpreted the development of system tracts are Transgressive System Tract and HighStand System Tract. While in the second line is HighStand System Tract. The analysis result of the system tract effect on the development of carbonate rock facies is at the beginning of the Tuban Formation deposition was controlled by the TST system tract and resulting the deposition of the reef core - fore reef facies. Then the change of system tract from TST to HST affects the development of reef core - fore reef facies into the development of backreef facies at the end of Tuban Formation in Jebori Field. Reef core is very good for reservoir to store the carbon dioxide compounds $\left(\mathrm{CO}_{2}\right.$ storage).

\section{References}

1. Joint Operating Body Pertamina-Petrochina East Java., 2006, FInal Well Report, Indonesia. (unpublished).

2. Satyana. A.H., 2002, Oligo-Miocene Reef : East Java's Giant Fields. Proceedings Of an Giant Field and New Exploration Concepts Seminar, October 2002: Indonesian Association Of Geologists (IAGI).

3. Smyth, H.R., Hall, R., dan Nichols, G.J., 2008, Cenozoic Vocanic Arc History of East Java, Indonesia: The Stratigraphic record of eruptions on an Active Continental Margin, Specil Paper 436, 2008: The Geological Soicety of America.

4. Smyth, H., Hall, R., Joseph, H., dan Pete, K., 2005, East Java: Cenozoic Basins, Volcanoes and Ancient Basement. Proceedings Of an Thirtieth Annual Convention \& Exhibition, August 2005: International Petroleum Association.

5. Gaillot, P., Brewer, T., Pezard, P., dan Yeh, E.C., 2007, Borehole Imagaging Tools-Principles and Applications, Scientific Drilling.

6. Petrowiki., 2015, Borehole Imaging. Electrical Imaging. http://petrowiki.org/Borehole_imaging \#Electrical_imaging (accessed on March 2017).

7. Schlumberger., 2013, FMI-HD High Defenition formation microimager, www.slb.com/fmi-hd (accessed on June 2017).

8. Shahinpour, A., 2013, Borehole image log analysis for sedimentary environment and clay volume interpretation, Norwegian University of Science and Technology: Halge Langeland, IPT.

9. Mastoadji, E.K., 2007, Basic Well Log Interpretation, Handout of AAPG SC UNDIP Course. 
10. Rider, M., 2002, The Geological Interpretation of Well Logs 2nd Edition, Malta: Interprint Ltd.I

11. Posamentier, H.W., dan Allen, G.P., 1999, Siliciclastic sequence stratigraphy: concepts and applications, SEPM Concepts in Sedimentology and Paleontology no. 7, 209 p.
12. Putra, S.P., 2007, Sekuen Pengendapan Sedimen Miosen Tengah Kawasan Selat Madura. Jurnal Riset Geologi \& Pertambangan Jilid 17 No 1 20-36. Bandung.

13. Satyana. A.H., 2005, Oligo-Miocene Carbonates Of Java, Inonesia: Tectonic-Volcanic Setting and Petroleum Implications, Proceedings Of an Thirtieth Annual Convention \& Exhibition, August 2005: International Petroleum Association. 